\title{
Fear of Crime and Saving Behavior
}

\author{
TRISTAN A. CANARE \\ Asian Institute of Management R.S. Navarro Policy Center for Competitiveness ${ }^{* \dagger}$ \\ JAMIL PAOLO S. FRANCISCO \\ Asian Institute of Management R.S. Navarro Policy Center for Competitiveness
}

EDGARDO MANUEL MIGUEL M. JOPSON

Asian Institute of Management R.S. Navarro Policy Center for Competitiveness

\begin{abstract}
Fear of crime, on top of crime victimization itself, is an important social concern because the literature suggests that it can affect behavior and decision-making. Some studies argue that negative emotions can induce present consumption; thus, one behavior that crime can potentially influence is saving. Applying Logit model and the Heckman Probit model to a household survey dataset of 1,200 respondents, this paper tested for the relationship between fear of crime and saving behavior. We found evidence that fear of crimes involving physical violence has a negative relationship with the likelihood of saving but has a positive relationship with the likelihood of saving through formal channels. Fear of crimes against property, on the other hand, shows no such relationship. Moreover, overall fear of crime in the immediate community has no relationship with saving, but fear of crime in the larger region where the individual lives has.
\end{abstract}

Keywords: fear; crime; saving; Heckman Probit model

JEL Classifications: D14; Z13; D01; D12

\section{Introduction and Objectives}

This paper investigates the relationship between fear of crime and saving decisions using data from a household survey conducted in Metro Manila, Philippines. Specifically, it attempts to

\footnotetext{
* The authors thank Timothy Joseph Henares for the research assistance, the Konrad Adenauer Stiftung for the financial support, and an anonymous referee and the editor, Jurek Konieczny, for the comments that substantially improved this paper. All remaining errors are the responsibility of the authors. All views expressed herein are solely of the authors and do not reflect the official position of any institution.

$\dagger$ Asian Institute of Management, 123 Paseo de Roxas, Makati City, Metro Manila, Philippines, tristan.canare@gmail.com.

(C) 2019 Tristan A. Canare, Jamil Paolo S. Francisco and Edgardo Manuel Miguel M. Jopson. Licensed under the Creative Commons Attribution - Noncommercial 3.0 License (http://creativecommons.org/licenses/by-nc/3.0/. Available at http: //rofea.org.
} 
study two relationships. First is between fear of crime and whether the individual saves part of his/her income or not. The second is between fear of crime and whether the individual uses formal or informal means of saving. In addition, we differentiated between general fear of crime and fear of specific crimes, particularly crimes that involve physical violence and crimes against property.

Fear of crime can induce uncertainty; and uncertainty about the future induces one to save as a precautionary measure (Ghosh and Ostry, 1997; Guiso et al., 1992). However, some studies argue that visceral factors like fear can induce consumption to compensate for the negative emotions attached to these factors (Loewenstein, 2000).

This paper found evidence that fear of some crimes is associated with saving behavior. Specifically, fear of crimes that involve physical violence is associated with lower probability of saving, but higher likelihood of saving through formal means. Fear of crimes against property, however, showed no such relationship. In addition, results suggest that general fear of crime in one's immediate neighborhood has no significant relationship with saving behavior. On the contrary, general fear of crime in the larger region where a person lives is associated with lower probability of saving but higher likelihood of saving through formal means.

Crime and fear of crime are two inter-related but separate concerns. For instance, a survey by Garcia et al (forthcoming) found that there is a much higher share of respondents who believe that they are likely to become victims of crime than the share of those who reported that they were actually victimized by crime. While crime itself is a crucial concern, fear of crime is also an important social issue because it can alter behavior, decision-making, mobility, and thought patterns (Doran and Burgess, 2012; Jackson and Gray, 2010; De Mello and Zilberman, 2008; Bennett, 1991; Moore and Trojanowicz, 1988; Clotfelter, 1977).

The literature on fear of crime has been existing and growing over the past few decades (Hale, 1996). Many of the empirical papers on this topic focused on the determinants of fear of crime and the effect of fear of crime on social and development outcomes (see the literature review section for examples). And while conceptual and theoretical studies have argued that negative emotions affect economic decisions (Loewenstein, 1996; 2000), the empirical literature focusing specifically on fear of crime and its relationship with economic decisions is still relatively thin. A few empirical papers on the relationship between negative emotions and saving (e.g. Kapoor 2008; Prelec and Loewenstein 1998) used data from small non-random experiments and surveys conducted in high-income countries. Using data from a developing economy may show different results due to differences in economic and social settings. This article's contribution to the literature is an attempt to fill this gap. Other papers studied the relationship between crime (rather than fear of crime) and economic behavior (e.g. De Mello and Zilberman (2008) for savings; Deininger (2003) for investments and business startups). Comparing the results of these existing studies with this paper offers additional insights and contributions to the literature. 


\section{CANARE, FRANCISCO AND JOPSON Fear and Crime Saving Behavior}

This paper is organized as follows. This brief introduction is followed by a review of relevant literature. Next, a theoretical framework on how fear influences saving and consumption decisions are discussed. This is followed by the data source, the econometric model used, and a presentation and discussion of the regression results and their implications. A short summary concludes the paper.

\section{Review of Related Literature}

\subsection{Effects of Uncertainty, Emotions, and Psychological Factors on Saving Behavior}

Uncertainty, emotions, and other psychological factors matter for consumer decisions (Loewenstein, 1996; 2000; Kapoor, 2008; Ghosh and Ostry, 1997). This is the primary motivation for studying whether fear is associated with saving behavior. Fear is a strong emotion and it can indicate uncertainty; while whether and how to save are decisions that consumers face regularly. And while the socio-economic and demographic determinants of saving are well-studied and widespread in the literature, how uncertainty and psychological factors influence saving are not as common, although still prevalent. This sub-section discusses the literature on how uncertainty and psychological factors are associated with saving behavior.

Early theoretical models by Sandmo (1970), Leland (1968), Sibley (1975), and Skinner (1988), and a later model by Miao (2004) explained how uncertainty can induce a consumer to save using the usual model of intertemporal utility maximization. In these models, savings protect an individual against the possibility of low future consumption when income is uncertain. Sandmo added that uncertainty of future income incentivizes an individual to save because savings increases expected future income, which in turn compensates for the uncertainty.

The theoretical literature on this topic looks mostly at income uncertainty, and empirical studies have studied different forms and measures of income uncertainty. Using the case of the 1989 political unrest in China, Aaberge et al. (2017) found evidence that political uncertainty induced a temporary increase in savings. Giavazzi and McMahon (2012) found a similar effect of political uncertainty using the case of the 1998 German election. Dustmann et al. (2017) compared savings and consumption patterns between documented and undocumented immigrants in Italy; and concluded that the latter saves more, attributing it to uncertainty of future income. Kazarosian (1997) built an income uncertainty indicator using panel data of more than 5,000 individuals from the United States. The author concluded that income uncertainty is positively associated with wealth as a proportion of permanent income, which is a measure of saving intensity.

Meanwhile, studies such as Chamon et al. (2013), Caballero (1991), and Guiso et al. (1992) attempted to compute for the share of savings due to income uncertainty in specific country 
cases. All found evidence that income uncertainty is associated with saving but its share on total savings varied widely.

Rather than future income uncertainty, Van Schie et al. (2012) looked at retirement savings adequacy uncertainty. The authors concluded that individuals who are uncertain if their future accumulated savings will be adequate have greater intention to save, provided that they think they are saving enough at present. A similar study by Murata (2003) using data from Japanese households concluded that those who expressed uncertainty over the country's public pension system have higher savings.

Turning to the psychological factors of saving, the literature looked at how emotions and personality types are associated with saving decisions. Empirically, Guven (2012) found evidence that happier individuals save more using household data from Germany and the Netherlands. Using data from a student survey, Kapoor (2008) concluded that strong negative emotions, particularly spite and desire for revenge, can induce present consumption and therefore negatively influence savings. Using the results of a psychometric test among more than 2,000 people in four Southeast Asian countries, Brahmana and Brahmana (2016) found evidence that positive "mood" and negative "mood" are, respectively, associated with higher and lower savings.

The literature has even looked at personality types and how they are correlated with saving behavior. Brahmana and Brahmana (2016) concluded that aggressive behavior is associated with lower savings. Using a United States survey data, Rha et al. (2006) found evidence that self-control, as measured by the presence of saving rules and saving goals and the ability to foresee a future major expense, is positively associated with the likelihood of saving. Similarly, Watson (2003) used survey data from the U.S. and found a negative relationship between degree of materialism and the propensity to save.

The foregoing discussions suggest that most theoretical and empirical literature show that uncertainty can positively influence saving, but strong negative emotions have the opposite effect. When a variable - such as fear - brings both uncertainty and negative emotions, its relationship with saving may depend on which effect is stronger. Loewenstein et al. (2001) presented a conceptual framework on how emotions can affect the decision-making process in the presence of risk and uncertainty; and how decisions based on rational cognitive analysis can differ with decisions based on emotions. This framework claims that when an individual is faced with risky alternatives, he/she makes choices based on cognitive analysis and on emotional factors. Cognitive analysis makes use of the likelihood that each alternative will occur and their corresponding returns, or the standard expected utility approach. Emotions, on the other hand, are affected by anticipated outcomes and feelings attached to each alternative, the subjective probability that each alternative will occur, and the immediacy of the risk. Because cognitive analysis and emotional reactions are determined by different sets of factors, their effect on making choices can diverge and even contradict. 
CANARE, FRANCISCO AND JOPSON Fear and Crime Saving Behavior

\subsection{Fear and Fear of Crime}

It is important to note that crime and fear of crime are not necessarily associated with each other (DuBow, McCabe, and Kaplan, 1979; Hale 1996; Henig and Maxfield 1978), and it has been observed that fear of crime could be more widespread than crime itself (Hale 1996; Miceli, Roccato, and Rosato 2004; Taylor, Shumaker, and Gottfredson 1985). This suggests that a decrease in crime does not necessarily lead to a decrease in fear of crime. Once fear of crime is instilled, it may take more than anti-crime measures to allay public concern and reactions (Taylor and Hale, 1986).

In order to understand the root of fear of crime, we look at its determinants. Warr (1984, 1985, 1987), Warr and Stafford (1983), and Hale (1996) argue that there are two main factors that influence fear of crime - the risk of victimization and the seriousness of consequences. Even if there is low probability of victimization, a person can be afraid if being a victim has serious long-term effects. An example of this is rape, which explains why women generally have greater fear of crime. Some studies also suggest that fear of crime can be expressed as a function of physical and social vulnerability (Evans and Fletcher, 2000; Taylor and Hale, 1986; Skogan and Maxfield, 1981). The former can be found in openness to attack, ability to resist, and exposure to emotional and physical effects of becoming a victim of crime, while the later would refer to the level of exposure to victims of crime and the ability to cope with the consequences of becoming a victim of crime (Skogan and Maxfield, 1981). Both physical and social vulnerabilities are attributable to traits, behavior, and environment of the individual (Schafer, Huebner, Bynum, 2006).

There is a rich body of literature on other factors affecting fear of crime. Physical and social vulnerability (Evans and Fletcher, 2000; Taylor and Hale, 1986; Skogan and Maxfield, 1981), gender (Collins, 2016; Valera and Guàrdia, 2014; Skogan and Maxfield, 1981), old age (Valera and Guàrdia, 2014; Rader, Cossman, and Porter, 2012; Skogan and Maxfield, 1981), income (Rader, Cossman, and Porter, 2012; Meško et al., 2008; Warr and Ellison, 2000; Skogan and Maxfield, 1981), education (Hummelsheim et al., 2011; Dammert and Malone, 2003), past victimization of crime (Valera and Guàrdia, 2014; Dammert and Malone, 2003; Skogan and Maxfield, 1981; Balkin, 1979), and neighborhood characteristics (Foster, Giles-Corti, and Knuiman, 2010) are just some of the factors that affect fear of crime in the literature.

The fear of crime, on top of being victimized by crime, is a concern in itself because it can adversely affect the public. Fear can change behavioral and thought patterns, limit mobility, and affect decision making because of worries about protecting oneself (Doran and Burgess, 2012; Jackson and Gray, 2010; De Mello and Zilberman, 2008; Bennett, 1991; Moore and Trojanowicz, 1988; Clotfelter, 1977). Fear can also affect other aspects of society. It can increase support for authoritarianism and punitive policies (Klama and Egan, 2011; Wanner and Caputo, 1987; Taylor, Scheppele, and Stinchcombe, 1979; Sales, 1973), affect culture 
(Warr, 2000), and induce out migration from urban areas (Cullen and Levitt, 1999; Miethe, 1995; Skogan, 1986). Other societal effects of fear of crime include promoting urban violence and neighborhood decline (Cullen and Levitt, 1999; Miethe, 1995; Skogan, 1986) and debilitating development and diversification of local economies (Rios, 2015; Carboni and Detotto, 2013).

\section{Theoretical Framework}

\subsection{A Framework for Analyzing Fear and Consumption}

Microeconomic theory and some empirical studies (e.g. Ghosh and Ostry, 1997; Guiso et al., 1992; Wachtel, 1977) state that when faced with uncertainty and risk, a consumer may respond by hedging against the possible loss. For instance, the knowledge that the risk of theft is high may persuade the consumer to purchase an insurance or to save money. However, in some cases, risks and uncertainties are accompanied by strong negative emotions. The risk of being victimized by crime, for instance, is usually accompanied by fear because of the repercussions and stigma of being a crime victim. And according to literature, this negative emotion may induce a response that may contrast with the rational response to the uncertainty.

Loewenstein (1996) presented a theoretical framework on analyzing the relationship between visceral factors, such as fear, and human behavior including inter-temporal allocation of consumption. The framework starts with a utility function where utility is expressed as a function of consumption and visceral factors in different time periods (Equation 1).

$$
\mathrm{U}=\sum \mathrm{t} \mathrm{u}(\mathrm{xt} 1, \ldots, \mathrm{xtn}, \alpha \mathrm{t} 1, \ldots, \alpha \mathrm{tm}, \mathrm{t})
$$

Loewenstein defined visceral factors as psychological and physiological factors that can affect decision making adversely and can induce individuals to act against their own self-interest. It includes such factors as hunger, thirst, sexual desire, fear, pain, moods and emotions, and cravings for a drug the person is addicted to. According to the author, one defining characteristic of these visceral factors is that they disproportionately affect behavior to the point that mitigating it "crowds out" other objectives, inducing the individual to act irrationally.

In equation (1), $U$ is the total utility from consumption and visceral factors across different time periods, $\left(x_{t l}, \ldots, x_{t n}\right)$ is the consumption vector of goods 1 to $\mathrm{n}$ at time $\mathrm{t},\left(\alpha_{t l}, \ldots, \alpha_{t m}\right)$ is the vector of visceral factors 1 to $\mathrm{m}$ at time $\mathrm{t}$, and $t$ is time. Equation (1) can be modified such that visceral factors can be grouped into subsets that affect only one consumption good. A simple case of this modification can be shown using Equation (2), where each consumption good at time $t, x_{t l}$, is affected by at most one visceral factor at time $t, \alpha_{t l}$.

$$
\mathrm{U}=\sum_{\mathrm{t}} u\left(v_{l}\left(x_{t l}, \alpha_{t 1}, \mathrm{t}\right), \ldots, v_{n}\left(x_{t n}, \alpha_{t n}, t\right)\right)
$$




\section{CANARE, FRANCISCO AND JOPSON Fear and Crime Saving Behavior}

In Equation (2), $v_{l}\left(x_{t l}, \alpha_{t 1}, \mathrm{t}\right)$ is the utility from consuming consumption good $x_{l}$ at time $t$ given a level of visceral factor $\alpha_{1}$ at time $t$. Loewenstein (1996) formulated several arguments and used Equations (1) and (2) to express them mathematically.

One of these formulations is that increasing the level of a visceral factor increases the individual's valuation of consumption of goods today relative to consumption tomorrow. Using the notations in Equation (2), given two different levels of visceral factor, $\alpha$ and $\alpha$ ' and two levels of consumption good, $x$ and $x^{\prime}$, if $\alpha^{\prime}>\alpha$ and $v(x, \alpha, 0)=v\left(x^{\prime}, \alpha, t\right)$, then $v\left(x, \alpha^{\prime}, 0\right)>v\left(x^{\prime}\right.$, $\left.\alpha^{\prime}, t\right)$.

Loewenstein (2000) explained that the reason for this is that utility from consumption at present mitigates visceral factors, including fear, therefore increasing the marginal rate of substitution for delayed consumption. This translates to higher present consumption and lower savings. This argument was empirically supported by Kapoor (2008), who found evidence that negative emotions can indeed induce present consumption using qualitative data from 117 college students. De Mello and Zilberman (2008) identified another reason why crime, and fear of crime by extension, can be negatively associated with savings - it induces additional security spending.

The preceding discussion implies that the relationship between fear, specifically fear of crime, and saving depends on which effect is stronger. The uncertainty brought by fear can induce the individual to save to hedge against possible loss. On the other hand, present consumption mitigates the negative emotional effect of fear, providing incentive to consume at present rather than save.

On the other hand, the relationship between fear of crime and saving through formal channels can work through a different mechanism. The literature suggests that uncertainty can induce individuals to minimize risk or risky activities (Thaler et al 1997; Cukierman 1980; Marquis and Reitz 1969; Sandmo 1970); and formal banking institutions are the least risky in terms of returns and in terms of physical security of the savings. Therefore, we can hypothesize a positive relationship between fear of crime and saving through formal means.

\section{Methodology}

\subsection{Data and Data Source}

The dataset was generated from a multi-stage random survey among 1,200 households in Metro Manila, Philippines. Metro Manila is an agglomeration of 17 cities including the national capital, Manila. The entire Metro Manila region has a population of almost 12.9 million or about 12.8 percent of the national total as of 2015. In the same year, it accounted for 37 percent of national Gross Domestic Product (GDP); and its nominal per capita regional GDP of around USD8,700 is nearly three times the national average. Services account for more than $80 \%$ of the regional GDP led by trading, real estate, and finance, with manufacturing also contributing 
significantly. The employment rate is 93.1 percent, lower than the national average of 94.2 percent.

The sample size per city is proportionally distributed based on the population size of each of the 17 component cities of Metro Manila. Sampled barangays or "villages" were randomly drawn from each congressional district in each city, and respondent households were drawn using systematic random sampling from each barangay. Starting from pre-determined points based on road maps of sampled barangays, enumerators counted-off to the 10th house and attempted to conduct an interview. If the 10th household declined to participate, the enumerator proceeded to the next house. After each successful interview, the enumerator counted-off to the 10th house thereafter, conducted the next interview, and so on, until the target number of households to be interviewed in the barangay is met. The interviews were conducted in the local Filipino language.

The survey instrument consists of questions regarding victimization and fear of crime, perceptions of authority, socio-economic insecurities, political views and behavior, media consumption, and socio-demographic indicators. It also includes several fear of crime questions patterned after Collins (2016). Specific crimes were adopted from the Social Weather Stations (2016) and the Neighborhood Watch Crime Perception Survey of the Sanford, North Carolina Police Department (2007). The community problem questions were patterned after the 2012 to 2013 Crime Survey for England and Wales (Office for National Statistics, 2012); and the other insecurity questions from Dammert and Malone (2003). Illegal drug-related items were adopted from several instruments of the European Monitoring Centre for Drugs and Drug Addiction. The instrument was pre-tested in two barangays.

The survey also asked the respondents if they are able to save some of their income, along with where they keep these savings. The choices are "store money at home", "deposit money in a bank", "contribute to a cooperative or pooled fund", and "others".

\subsection{Measuring Fear of Crime}

Farrall et al (1997), Ferraro and LaGrange (1987), and Hale (1996) distinguished between 'concrete' and 'formless' fear of crime. The former refers to specific crimes such as those used in this paper, while the latter refers to the general emotional fear of crime. Ferraro and LaGrange (1987) and Hale (1996) also issued some general reminders on survey-based quantitative measures of fear of crime. For one, questions should explicitly mention crime, rather than using vague or implicit reference to crime. Questions such as 'Are you afraid of being victimized by crime?' is preferred over 'Are you afraid to walk outside of your house at night?' Another is to avoid hypotheticals such as 'Will you be afraid if you would walk outside?' Instead, ask 'Do you currently feel safe from crime?'

Two types of fear of crime were tested for their relationship with saving behavior - general fear of crime and fear of specific crimes. For general fear of crime, we also differentiated 


\section{CANARE, FRANCISCO AND JOPSON Fear and Crime Saving Behavior}

between fear of crime within the respondent's immediate neighborhood and fear of crime in Metro Manila as a whole. The five specific crimes included were pickpocketing (fear_pickpocket), burglary (fear_burglary), vehicle theft (fear_vehicle), rape or attempted rape (fear_rape), and physical violence other than rape (fear_physviolence).

The general fear of crime variables were captured by the questions "I feel safe from crime in this neighborhood" and "I feel safe from crime in Metro Manila", with the following possible answers: "Strongly Agree", "Agree", "Neutral", "Disagree”, and "Strongly Disagree”. For each of the five specific crimes, the question was "How likely are you to become a victim of [specific crime] in the next 12 months?". The possible answers follow a Likert rating scale of fear of future victimization (Britto, 2013; Dammert and Malone, 2003, 2006) as follows: "very likely", "somewhat likely", "somewhat unlikely", "very unlikely", and "don't know".

For the general fear of crime, two variables were constructed - one represents fear of crime in the respondent's immediate neighborhood (fear_neigh) and the other represents fear of crime in Metro Manila (fear_mm). We included the fear of crime in Metro Manila because most residents of the region do not just stay in their neighborhood. They study, work, or visit other areas or other cities within the metropolis, and thus their fear of crime in Metro Manila may affect their decisions. Each variable assigns a value of 1 if the respondent answers "strongly agree", 2 for "agree", 3 for "neutral", 4 for "disagree", and 5 for "strongly disagree". For the specific fear of crime variables, the values are 1 for "very unlikely", 2 for "somewhat unlikely", 3 for "don't know", 4 for "somewhat likely", and 5 for "very likely". This means that for the seven fear of crime variables, the higher the value, the greater the fear.

Warr and Stafford (1983) studied the inherent causes of fear of victimization for a variety of specific violent and property crimes. They asserted that fear of victimization is a function of the interaction between the perceived seriousness of a crime and the perceived risk of falling victim to that crime. As such, they found fear of violent crimes such as murder, which is very serious but unlikely to occur, to be far lower than fear of property crimes like residential burglary, which could be both serious and likely to occur. This is the primary reason for the use of different types of crime. It accounts for differences in likelihood to occur and seriousness.

\subsection{Empirical Strategy and Methodology}

This paper tests for the relationship between fear of crime and two aspects of saving - the likelihood of saving and the likelihood of saving through formal means. Logit regression was used for the first objective while the Heckman Probit Sample Selection Model, based on Heckman (1979) but with binary outcome dependent variable, was used for the second. The Heckman Probit model was used because data on saving through formal means is only available for respondents who actually save. Thus, data is censored on those who do not save. There is a sample selection bias because data on where savings are placed is available only for those with savings. 
We used the seven fear of crime variables in separate regressions. Thus, these models were estimated:

$$
\begin{aligned}
& \text { savings }=\alpha+\beta^{*} \text { fear }+\delta^{*} X+\mu \\
& \text { formal }=\zeta+\theta^{*} \text { fear }+\varsigma^{*} Z+\eta
\end{aligned}
$$

where savings is a dummy variable $=1$ if the respondent saves part of his/her income, formal is a dummy variable $=1$ if the respondent saves through formal means ("bank" in the question asking where do respondents place their savings), fear represents each of the seven fear of crime variables, $\beta$ and $\theta$ are their coefficients, $X$ and $Z$ are vectors of control variables and $\delta$ and $\varsigma$ are their coefficients, and $\alpha$ and $\zeta$ are constants. The variables $\mu$ and $\eta$ are error terms.

For each fear of crime variable, equation (3) was estimated using logit regression while equation (4) used Heckman Probit regression. For the Heckman regression, equation (4) is the outcome equation. The selection equation used the variable savings as the dependent variable and the independent variables are those used in equation (3). As a requirement for efficient Heckman estimates, some variables in $X$ are not in $Z$.

The control variables included were socio-demographic indicators including age, sex, educational attainment, income, employment status, number of children, and marital status. Also included were neighborhood characteristics that were derived from the survey, including an index of perceived neighborhood problems identified by the respondents and an indicator of being victimized by crime. Also included are number of hours of exposure to different media per day and respondent's perception of whether he/she is relatively richer or poorer than his/her neighbors. The variables used and their summary statistics are detailed in Table 1. A quick look at the table shows that almost half (44 percent) of survey respondents save some parts of their income. Among those who save, 61 percent keep their savings through formal means (banks).

\section{Results and Discussions}

\subsection{Regression results}

\section{Fear and saving}

The average marginal effects after Logit of the regressions involving the specific crimes are reported in Table 2, and those involving general fear of crime are in Table 3. The results of the Heckman regressions involving specific crimes are in Table 4, and those for general fear of crime are reported in Table 5. Note that only the fear variables and some regression statistics are shown in Tables 2 to 5; the complete regression tables are in the Appendix. 
CANARE, FRANCISCO AND JOPSON Fear and Crime Saving Behavior

Table 1: Variable Description and Summary Statistics.

\begin{tabular}{|c|c|c|c|c|c|}
\hline Variable Name & Description & Mean & SD & Min & Max \\
\hline savings & $\begin{array}{l}\text { Dummy }=1 \text { if respondent saves part of his/her } \\
\text { income }\end{array}$ & 0.438 & 0.496 & 0 & 1 \\
\hline formal & $\begin{array}{l}\text { Dummy }=1 \text { if respondent keeps savings in } \\
\text { formal channels (banks) }\end{array}$ & 0.605 & 0.489 & 0 & 1 \\
\hline fear_neigh & $\begin{array}{l}\text { Answer to the question: "I feel safe from crime } \\
\text { in this neighborhood". =1 if Strongly agree; =2 } \\
\text { if Agree; =3 if Neutral; =4 if Disagree; =5 if } \\
\text { Strongly disagree. }\end{array}$ & 2.321 & 0.847 & 1 & 5 \\
\hline fear_mm & $\begin{array}{l}\text { Answer to the question: "I feel safe from crime } \\
\text { in Metro Manila". =1 if Strongly agree; =2 if } \\
\text { Agree; =3 if Neutral; =4 if Disagree; =5 if } \\
\text { Strongly disagree. }\end{array}$ & 2.891 & 0.879 & 1 & 5 \\
\hline fear_pickpocket & $\begin{array}{l}\text { Likelihood of being a victim of pickpocketing: } \\
=1 \text { if Very unlikely; }=2 \text { if Somewhat unlikely; } \\
=3 \text { if Don't know; }=4 \text { if Somewhat likely; }=5 \text { if } \\
\text { Very likely. }\end{array}$ & 2.578 & 1.162 & 1 & 5 \\
\hline fear_burglary & $\begin{array}{l}\text { Likelihood of being a victim of burglary: }=1 \text { if } \\
\text { Very unlikely; }=2 \text { if Somewhat unlikely; }=3 \text { if } \\
\text { Don't know; =4 if Somewhat likely; =5 if Very } \\
\text { likely. }\end{array}$ & 2.507 & 1.156 & 1 & 5 \\
\hline fear_vehicle & $\begin{array}{l}\text { Likelihood of being a victim of vehicle theft: }=1 \\
\text { if Very unlikely; }=2 \text { if Somewhat unlikely; }=3 \text { if } \\
\text { Don't know; =4 if Somewhat likely; }=5 \text { if Very } \\
\text { likely. }\end{array}$ & 2.255 & 1.091 & 1 & 5 \\
\hline fear_rape & $\begin{array}{l}\text { Likelihood of being a victim of rape or } \\
\text { attempted rape: }=1 \text { if Very unlikely; }=2 \text { if } \\
\text { Somewhat unlikely; }=3 \text { if Don't know; }=4 \text { if } \\
\text { Somewhat likely; }=5 \text { if Very likely. }\end{array}$ & 2.231 & 1.091 & 1 & 5 \\
\hline fear_physviolence & $\begin{array}{l}\text { Likelihood of being a victim of physical } \\
\text { violence other than rape: }=1 \text { if Very unlikely; }=2 \\
\text { if Somewhat unlikely; }=3 \text { if Don't know; }=4 \text { if } \\
\text { Somewhat likely; }=5 \text { if Very likely. }\end{array}$ & 2.292 & 1.112 & 1 & 5 \\
\hline age & Age of respondent & 48.122 & 14.326 & 19 & 85 \\
\hline sex & $=1$ if female & 0.679 & 0.467 & 0 & 1 \\
\hline
\end{tabular}


Table 1 continued.

\begin{tabular}{|c|c|c|c|c|c|}
\hline educ ${ }^{*}$ & $\begin{array}{l}=1 \text { if respondent has some elementary education } \\
\text { or lower }\end{array}$ & 0.030 & 0.171 & 0 & 1 \\
\hline educ2 & $=1$ if respondent reached high school & 0.153 & 0.360 & 0 & 1 \\
\hline educ3 & $=1$ if respondent is a high school graduate & 0.293 & 0.455 & 0 & 1 \\
\hline educ4 & $\begin{array}{l}=1 \text { if respondent has vocational degree or } \\
\text { reached college }\end{array}$ & 0.277 & 0.448 & 0 & 1 \\
\hline educ5 & $=1$ if respondent is a college graduate & 0.248 & 0.432 & 0 & 1 \\
\hline inc1* & $\begin{array}{l}=1 \text { if low income level ( } \mathrm{PhP} 0 \text { to } 15,000 \text { per } \\
\text { month; US } \$ 1 \text { is equal to around PhP46 at the } \\
\text { time of the survey) }\end{array}$ & 0.426 & 0.495 & 0 & 1 \\
\hline inc2 & \begin{tabular}{|l}
$=1$ if medium income level ( $\mathrm{PhP} 15,001$ to \\
80,000 per month)
\end{tabular} & 0.530 & 0.499 & 0 & 1 \\
\hline inc3 & $\begin{array}{l}=1 \text { if high income level (above } \mathrm{PhP} 80,000 \text { per } \\
\text { month) }\end{array}$ & 0.044 & 0.206 & 0 & 1 \\
\hline employed & $=1$ if respondent is employed & 0.633 & 0.482 & 0 & 1 \\
\hline separate & $=1$ if respondent is separated/divorced/widowed & 0.148 & 0.356 & 0 & 1 \\
\hline single & $=1$ if respondent is single & 0.101 & 0.301 & 0 & 1 \\
\hline married* & $=1$ if respondent is married & 0.751 & 0.433 & 0 & 1 \\
\hline victim & $=1$ if respondent has been a crime victim & 0.403 & 0.491 & 0 & 1 \\
\hline neighprob & Index for neighborhood problems & 2.806 & 0.701 & 1 & 5 \\
\hline media & $\begin{array}{l}\text { Combined number of hours per day spent } \\
\text { watching TV, listening to radio, reading } \\
\text { newspaper, reading news on the internet, and } \\
\text { browsing social media. }\end{array}$ & 6.071 & 4.787 & 0 & 37 \\
\hline children & $\begin{array}{l}\text { Number of household members } 18 \text { years old and } \\
\text { below }\end{array}$ & 1.691 & 1.610 & 0 & 15 \\
\hline richer & $\begin{array}{l}=1 \text { if respondent says he/she is relatively richer } \\
\text { than his/her neighbors }\end{array}$ & 0.074 & 0.262 & 0 & 1 \\
\hline poorer & $\begin{array}{l}=1 \text { if respondent says he/she is relatively poorer } \\
\text { than his/her neighbors }\end{array}$ & 0.058 & 0.234 & 0 & 1 \\
\hline
\end{tabular}

* Base variable; not included in the regression. Shown only for reference. 


\section{CANARE, FRANCISCO AND JOPSON Fear and Crime Saving Behavior}

The marginal effects of all specific fear of crime variables on the likelihood of saving are negative, but only those of rape and physical violence are statistically significant. Fear of pickpocketing, burglary, and car theft all turned insignificant. Turning to general fear of crime, the marginal effect of fear in the immediate neighborhood is insignificant but fear in Metro Manila as a whole is negative and significant. These results suggest that fear of crimes against property has no significant relationship with the likelihood of saving, but fear of crime that involves physical violence is associated with lower probability of saving. Moreover, general fear of crime in one's neighborhood has no significant relationship with the probability of saving; but respondents who do not feel safe from crime in Metro Manila as a whole are less likely to save.

These results show some evidence that fear of crime is negatively associated with the likelihood that a person will save. That is, people who are more afraid are less likely to save. This relationship, however, is captured only by fear of crimes that involve physical violence and not by fear of crimes against property. In addition, the results show that the relationship is captured by fear of crime in Metro Manila as a whole, rather than fear of crime in the person's own neighborhood.

Other than the variables of interest, the sign of the coefficients of most control variables were not unexpected. Number of children has a negative relationship with the likelihood of saving. Age has a negative and significant coefficient while age squared is positive and significant. This means that as people get older, they are less likely to save but at a certain age, this relationship reverses. Respondents who are employed and those with higher educational attainment and income have higher probability of saving. In addition, individuals who think that they are relatively richer than their neighbors are more likely to save; and those relatively poorer are less likely to do so. Exposure to media also has a positive relationship with the probability of saving.

\section{Fear and Saving Through Formal Means}

While the logit regressions show the relationship between fear of crime and the likelihood of saving, the outcome equations of the Heckman Probit regressions show the relationship between fear of crime and where savings are placed. All of the five individual crime variables showed positive coefficients, but only fear of rape turned significant. Fear of pickpocketing, burglary, vehicle theft, and physical violence other than rape all turned insignificant (although the significance of physical violence is near the $10 \%$ threshold).

There is also evidence that general fear of crime is associated with saving through formal means. And like the earlier result, it is the general fear of crime for the whole of Metro Manila that exhibits this result with its positive and significant coefficient. In contrast, general fear of crime in the immediate neighborhood turned positive but insignificant. That is, individuals who 
are generally more afraid of crime are more likely to keep their savings in banks than use informal methods such as keeping the money inside the house. In addition, it is fear of crime in Metro Manila that shows such results; not fear in one's neighborhood.

Some control variables also turned significant. Older people, those with higher income, those who are single, and to some extent, the more educated, are more likely to save through formal means. The Wald test of independent equations in all regression models is statistically significant, indicating that there really is selection bias and that the selection and outcome equations cannot be run separately. This supports our use of the Heckman Probit technique.

Although our interest in the Heckman regressions are with the outcome equation, it is worth mentioning that the results of the selection equation are, expectedly, almost the same as that of the logit regressions. Fear of rape and physical violence and fear of crime in Metro Manila have negative and significant coefficients in the selection equation, while fear of pickpocketing, burglary, and car theft and fear of crime in the neighborhood are insignificant. Education, income, employment, exposure to media, and the impression that one is relatively richer than the neighbors also have positive and significant coefficients. On the other hand, number of children and the impression that one is relatively poorer than the neighbors have negative and significant coefficients.

Table 2. Logit Average Marginal Effects (Variables of Interest: Fear of Specific Crimes).

\begin{tabular}{|l||c|c|c|c|c|}
\hline \multirow{2}{*}{ Variable } & $(1)$ & $(2)$ & $(3)$ & $(4)$ & $(5)$ \\
\cline { 2 - 6 } & \multicolumn{2}{|c|}{ Dep. Var. = Dummy $=\mathbf{1}$ if respondent saves; =0 otherwise } \\
\hline & & & & & \\
\hline fear_pickpocket & -0.013 & & & & \\
\hline & $(0.012)$ & & & & \\
\hline fear_burglary & & -0.007 & & & \\
\hline & & $(0.012)$ & & & \\
\hline fear_vehicle & & & -0.009 & & \\
\hline & & & $(0.012)$ & & \\
\hline fear_rape & & & & $-0.023^{*}$ & \\
\hline & & & & $(0.012)$ & \\
\hline fear_physviolence & & & & & $-0.022^{*}$ \\
\hline & & & & & $(0.012)$ \\
\hline & & & & & \\
\hline & 1,179 & 1,179 & 1,179 & 1,179 & 1,179 \\
\hline Observations & 0.1682 & 0.1677 & 0.1678 & 0.1696 & 0.1695 \\
\hline Pseudo R-squared & & & & & \\
\hline
\end{tabular}

Standard errors in parentheses; $* * * \mathrm{p}<0.01,{ }^{* *} \mathrm{p}<0.05, * \mathrm{p}<0.1$

Note: The complete table is in the appendix. 
CANARE, FRANCISCO AND JOPSON Fear and Crime Saving Behavior

Table 3. Logit Average Marginal Effects (Variables of Interest: General Fear of Crime).

\begin{tabular}{|c|c|c|}
\hline \multirow[b]{2}{*}{ Variable } & $(1)$ & (2) \\
\hline & \multicolumn{2}{|c|}{$\begin{array}{l}\text { Dep. Var.: Dummy }=1 \text { if } \\
\text { respondent saves; }=0 \text { otherwise }\end{array}$} \\
\hline \multirow[t]{2}{*}{ fear_neigh } & -0.013 & \\
\hline & $(0.016)$ & \\
\hline \multirow[t]{2}{*}{ fear_mm } & & $-0.036 * *$ \\
\hline & & $(0.015)$ \\
\hline Observations & 1,179 & 1,179 \\
\hline Pseudo R-squared & 0.1678 & 0.1710 \\
\hline
\end{tabular}

Standard errors in parentheses; $* * * \mathrm{p}<0.01, * * \mathrm{p}<0.05, * \mathrm{p}<0.1$

Note: The complete table is in the appendix.

Table 4. Heckman Probit Regression Coefficients (Variables of Interest: Fear of Specific Crimes).

\begin{tabular}{|c|c|c|c|c|c|}
\hline \multirow[b]{2}{*}{ Variable } & (1) & $(2)$ & (3) & (4) & (5) \\
\hline & \multicolumn{5}{|c|}{$\begin{array}{c}\text { Outcome Equation (Dep. Var.: Dummy }=1 \text { if respondent saves } \\
\text { through formal means; }=0 \text { otherwise) }\end{array}$} \\
\hline \multirow[t]{2}{*}{ fear_pickpocket } & 0.043 & & & & \\
\hline & $(0.050)$ & & & & \\
\hline \multirow[t]{2}{*}{ fear_burglary } & & 0.041 & & & \\
\hline & & $(0.050)$ & & & \\
\hline \multirow[t]{2}{*}{ fear_vehicle } & & & 0.035 & & \\
\hline & & & $(0.049)$ & & \\
\hline \multirow[t]{2}{*}{ fear_rape } & & & & $0.096 * *$ & \\
\hline & & & & $(0.049)$ & \\
\hline \multirow[t]{2}{*}{ fear_physviolence } & & & & & 0.061 \\
\hline & & & & & $(0.050)$ \\
\hline Observations & 1,179 & 1,179 & 1,179 & 1,179 & 1,179 \\
\hline Uncensored Obsns & 516 & 516 & 516 & 516 & 516 \\
\hline Wald test of indep. eqns. (p-value) & 0.0695 & 0.0608 & 0.0624 & 0.0519 & 0.0633 \\
\hline
\end{tabular}

Robust standard errors in parentheses; $* * * \mathrm{p}<0.01,{ }^{* *} \mathrm{p}<0.05,{ }^{*} \mathrm{p}<0.1$

Note: The complete table is in the appendix. 
Table 5. Heckman Probit Regression Coefficients (Variables of Interest: General Fear of Crime).

\begin{tabular}{|c|c|c|}
\hline \multirow[b]{2}{*}{ Variable } & (1) & $(2)$ \\
\hline & \multicolumn{2}{|c|}{$\begin{array}{c}\text { Outcome Equation (Dep. Var.: } \\
\text { Dummy }=1 \text { if respondent saves } \\
\text { through formal means; }=0 \\
\text { otherwise) }\end{array}$} \\
\hline fear_neigh & $\begin{array}{c}0.081 \\
(0.064)\end{array}$ & \\
\hline fear_mm & & $\begin{array}{c}0.146 * * \\
(0.063)\end{array}$ \\
\hline Observations & 1,179 & 1,179 \\
\hline Uncensored Obsns & 516 & 516 \\
\hline Wald test of indep. eqns. (p-value) & 0.0477 & 0.0560 \\
\hline
\end{tabular}

Robust standard errors in parentheses; *** $\mathrm{p}<0.01,{ }^{* *} \mathrm{p}<0.05,{ }^{*} \mathrm{p}<0.1$

Note: The complete table is in the appendix.

\subsection{Discussions and Implications}

Results suggest that fear of crime has a relationship with saving behavior, although it depends on how fear of crime is measured and on the aspect of saving. There is evidence that fear of crime is negatively associated with the probability of saving - that is, people who are more afraid are less likely to save - but this is observed only in specific crime measures. Crimes that involve physical violence are associated with lower probability of saving, but crimes against property are not. In addition, overall fear of crime in the whole of Metro Manila is also negatively associated with the likelihood of saving, but overall fear of crime in the immediate neighborhood is not.

The negative relationship between fear of crime and saving is supported by some studies in the literature. Kapoor (2008) and Loewenstein (2000) argue that present consumption is a coping mechanism to stress and uncertainty brought by negative emotions such as fear. Similarly, the model developed by Loewenstein (1996) shows how negative emotions like fear lead to greater discounting of the future. Greater discounting of the future means that an individual places greater value on the present, making present consumption much preferred over future consumption. An increase in present consumption reduces an individual's savings and the ability and willingness to save.

Fear of crime can have two opposing effects on saving. Uncertainty is an incentive to save (Ghosh and Ostry, 1997; Guiso et al., 1992; Wachtel, 1977), and fear can generate uncertainty. The knowledge that properties are at risk of being stolen may also discourage consumers from 


\section{CANARE, FRANCISCO AND JOPSON Fear and Crime Saving Behavior}

buying them, opting instead to save the money. Saving can also be considered as a rational response when a consumer is faced with a risk of loss. On the other hand, behavioral studies such as those cited above argue that negative emotions such as fear can induce consumption at present. It appears that in the case of fear of crime, the latter effect outweighs the former. This could suggest that the uncertainty brought by the rational fear of crime is not strong enough to induce a decision to save; and it is overpowered by the emotional fear, which induces present consumption.

The result that only crimes that involve physical violence turned statistically significant, whereas crimes against property did not, supports this interpretation. Crimes that involve physical violence such as rape, physical assault, homicide, and murder can arguably induce greater emotional distress than crimes against property such as burglary and theft.

Another result of interest is that general fear of crime in Metro Manila as a whole has a negative and significant relationship with saving, but general fear of crime in one's own neighborhood does not. In the survey, respondents have lower fear of crime in one's own neighborhood than in Metro Manila, implying that people generally feel safer in their own neighborhood than in the metropolitan area in general. That they feel safer in their own backyards could be the reason why fear in the immediate neighborhood has no relationship with their decision whether to save or not. The familiarity with one's own neighborhood and the unfamiliarity with other localities within the city could have induced this greater fear, and by extension, its greater effect on saving behavior.

Similar to the probability of saving, fear of crimes against property (pickpocketing, burglary, and vehicle theft) and overall fear of crime in the immediate neighborhood did not exhibit a relationship with the likelihood of saving through formal channels. In contrast, overall fear of crime in Metro Manila and fear of rape or attempted rape are associated with higher likelihood of saving through formal means. Individuals who have these types of fear are more likely to place their savings in formal financial institutions. Moreover, it is the fear of crime in Metro Manila as a whole, rather than in the respondent's neighborhood, that exhibits this positive relationship. Saving through formal means could be a response to fear. If a person is more afraid, he/she would want his/her assets to be more secured; and keeping them in a formal institution provides this security.

When compared with results of existing empirical literature, this study can offer insights into the effect of negative emotions on economic behavior, and on the differences between crime and fear of crime. A small survey of students by Kapoor (2008) found evidence that strong emotions, specifically spite and desire for revenge, may induce present consumption. A related experiment by Prelec and Loewenstein (1998) involving university students found evidence that the "pain of paying" when one buys something affects intertemporal allocation of consumption. 
Comparing the results with empirical studies on crime (rather than fear of crime) and its effect on economic behavior also offer additional insights. De Mello and Zilberman (2008) found a positive relationship between property crime and savings (but violent crime has no significant relationship) using the case of Brazil, while Deininger (2003) found no relationship between violence and theft crime and investments and startup businesses using Ugandan data. The divergence in results suggests that fear of crime and crime itself are different concerns and have differing effects on consumer behavior.

To summarize, results suggest that fear of crimes that involve physical violence is associated with lower probability of saving and with higher likelihood of saving through formal channels. In contrast, fear of crimes against property has no significant relationship with saving behavior. This could be attributed to physical violence crimes evoking more emotional distress to the victim than crimes against property. Moreover, fear of crime in Metro Manila as a whole is associated with lower likelihood of saving and higher probability of saving through formal means; but fear of crime in the neighborhood has no relationship with saving. This suggests that the relationship between fear and saving behavior is via the fear of crime in the larger geographic area that the individual lives in, rather than in the immediate neighborhood. In addition, the negative relationship between some indicators of fear of crime and saving suggests that the emotional response to the negative emotion of fear outweighs the positive effect on saving of the uncertainty brought by fear.

\section{Summary and Conclusions}

This paper attempts to determine the relationship between fear of crime and the likelihood of saving and of saving through formal means. Two forms of fear of crime were tested - that of specific crimes and general fear of crime. We also differentiated between fear of crime in Metro Manila as a whole and in the individual's immediate neighborhood.

Our results provide some evidence that fear of crime has a relationship with saving behavior. Specifically, fear of crimes that involve physical violence is associated with lower likelihood of saving and higher probability of saving through formal means. The same is observed for general fear of crime in Metro Manila. In contrast, fear of crimes against property and general fear of crime in the immediate neighborhood have no relationship with saving behavior.

These results have some implications. The negative relationship between some indicators of fear of crime and saving suggests that the emotional response to the negative emotion of fear outweighs the positive effect on saving of the uncertainty brought by fear. In addition, fear of crimes that involve physical violence - those that arguably cause greater emotional distress rather than fear of crimes against property drive this relationship. Finally, it is the fear of crime in one's larger environment - where one works, studies, or visits - rather than in his/her immediate neighborhood that is associated with saving behavior. 
CANARE, FRANCISCO AND JOPSON Fear and Crime Saving Behavior

\section{References}

Aaberge, R., Liu, K., \& Zhu, Y. (2017). Political Uncertainty and Household Savings. Journal of Comparative Economics, 45(1): 154-170

Balkin, S. (1979). Victimization Rates, Safety and Fear of Crime. Social Problems 26(3): 343358.

Bennett, T. (1991). The effectiveness of a police-initiated fear-reducing strategy. The British Journal of Criminology 31(1): 1-14.

Brahmana, R.K. \& Brahmana, R.K. (2016). Psychological Factors of Impulsive Savings Traits: Survey Carried out in Indonesia, Malaysia, Thailand, and Vietnam. International Journal of Happiness and Development, 3(1): 1-21.

Caballero, R. (1991). Earnings Uncertainty and Aggregate Wealth Accumulation. The American Economic Review, 81(4): 859-871.

Carboni, O.A. \& Detotto, C. (2013). The economic consequences of crime in Italy. CRENoS (Centro Ricerche Economiche Nord Sud) Working Paper No. 2013-03.

Chamon, M., Liu, K., \& Prasad, E. (2013). Income Uncertainty and Household Savings in China. Journal of Development Economics, 105(C): 164-177.

Clotfelter, C. (1977). Urban Crime and Household Protective Measures, The Review of Economics and Statistics, 59(4): 499-503.

Collins, R. (2016). Addressing the inconsistencies in fear of crime research: A meta-analytic review. Journal of Criminal Justice 47: 21-31.

Cukierman, A. (1980). The Effects of Uncertainty on Investment under Risk Neutrality with Endogenous Information. The Journal of Political Economy, 88(3): 462-475.

Cullen, J.B. \& Levitt, S.D. (1999). Crime, Urban Flight, and the Consequences for Cities, The Review of Economics and Statistics 81(2): 159-169.

Dammert, L. \& Malone, M.F.T. (2003). Does It Take a Village? Policing Strategies and Fear of Crime in Latin America. Latin American Politics and Society, 48(4): 27-51.

De Mello, J. \& Zilberman, E. (2008). Does Crime Affect Economic Decisions? An Empirical Investigation of Savings in a High-Crime Environment. The B.E. Journal of Economic Analysis \& Policy 8(1).

Deininger, K. (2003). Causes and Consequences of Civil Strife: Micro-Level Evidence from Uganda. Oxford Economic Papers 55(4): 579-606.

Doran, B.J. \& Burgess, M. (2012). Why is the Fear of Crime a Serious Social Problem. In B.J. Doran, \& M. Burgess (Eds.), Putting Fear of Crime on the Map: Investigating Perceptions of Crime Using Geographic Information Systems (p.9-23). New York: Springer.

DuBow, F., McCabe, E., \& Kaplan, G. (1979). Reactions to Crime: A Critical Review of Literature. Evanston, Illinois: National Institute of Law Enforcement and Criminal Justice, Law Enforcement Assistance Administration, U.S. Department of Justice. 
Dustmann, C., Fasani, F., \& Speciale, B. (2017). Illegal Migration and Consumption Behavior of Immigrant Households. Journal of the European Economic Association, 15(3): 654-691.

Evans, D. \& Fletcher, M. (2000). Fear of crime: testing alternative hypothesis. Applied Geography 20(4): 395-411.

Farrall, S., Bannister, J., Ditton, J., \& Gilchrist, E. (1997). Questioning the measurement of the 'fear of crime': Findings from a major methodological study. The British Journal of Criminology 37(4): 658-679.

Ferraro, K.F. \& LaGrange, R.L. (1987). The Measurement of Fear of Crime. Sociological Inquiry 57(1): 70-97.

Foster, S., Giles-Corti, B. \& Knuiman, M. (2010). Neighbourhood design and fear of crime: A social-ecological examination of the correlates of residents' fear in new suburban housing developments. Health and Place 16(6):1,156-1,165.

Garcia, E., Francisco, J.P.S., \& Caliso, R.A.C.C. (Forthcoming) Reassessing Fear of Crime: The Role of Broad Insecurities. Journal of Interdisciplinary Economics. DOI: https://doi.org/10.1177/0260107919829966

Ghosh, A.R. \& Ostry, J.D. (1997). Macroeconomic uncertainty, precautionary saving, and the current account. Journal of Monetary Economics 40(1): 121-139.

Giavazzi, F. \& McMahon, M. (2012). Policy Uncertainty and Household Savings. Review of Economics and Statistics, 94(2): 517-531.

Guiso, L., Jappelli, T., \& Terlizzese, D. (1992). Earnings, uncertainty, and precautionary saving. Journal of Monetary Economics 30(2): 307-337

Guven, C. (2012). Reversing the Question: Does Happiness Affect Consumption and Savings Behavior? Journal of Economic Psychology 33(4): 701-717.

Hale, C. (1996). Fear of Crime: A Review of the Literature. International Journal of Victimology 4(2): 79-150.

Heckman, J. (1979). Sample Selection Bias as a Specification Error. Econometrica, 47(1): 153161.

Henig, J. \& Maxfield, M.G. (1978). Reducing Fear of Crime: Strategies for Intervention. Victimology 3(3 \& 4): 297-313.

Hummelsheim, D., Hirtenlehner, H., Jackson, J., \& Oberwittler, D. (2011). Social insecurities and fear of crime: a cross-national study on the impact of welfare state policies on crimerelated anxieties. European Sociological Review, 27(3): 327-345.

Jackson, J. \& Gray, E., (2010). Functional Fear and Public Insecurities About Crime, The British Journal of Criminology, 50(1): 1-22.

Kapoor, H. (2008). Negative Emotions As Motivators of Consumption. In A.Y. Lee, \& D. Soman (Eds.), Advances in Consumer Research Volume 35 (p. 949-950). Duluth, MN: Association of Consumer Research. 
CANARE, FRANCISCO AND JOPSON Fear and Crime Saving Behavior

Kazarosian, M. (1997). Precautionary Savings - A Panel Study. Review of Economics and Statistics, 79(2): 241-247.

Klama, E.K. \& Egan, V. (2011). The Big-Five, sense of control, mental health and fear of crime as contributory factors to attitudes towards punishment. Personality and Individual Differences, 51(5): 613-617.

Leland, H. (1968). Saving and Uncertainty: The Precautionary Demand for Saving. The Quarterly Journal of Economics, 82(3): 465-473.

Loewenstein, G. (1996). Out of Control: Visceral Influences on Behavior. Organizational Behavior and Human Decision Processes, 65(3): 272-292.

Loewenstein, G. (2000). Emotions in Economic Theory and Economic Behavior. The American Economic Review, 90(2): 426-432.

Loewenstein, G., C. Hsee, E. Weber, \& N. Welch. (2001). Risk as Feelings. Psychological Bulletin 127(2): 267-286.

Marquis, D.G. \& Reitz, H.J. (1969). Effect of Uncertainty on Risk Taking in Individual and Group Decisions. Behavioral Science, 14(4): 281-288.

Meško, G., M. Fallshore, E. Muratbegovic, \& Fields, C. (2008). Fear of crime in two postsocialist capital cities - Ljubljana, Slovenia and Sarajevo, Bosnia and Herzegovina. Journal of Criminal Justice, 36(6): 546-553.

Miceli, R., Roccato, M., \& Rosato, R. (2004). Fear of Crime in Italy: Spread and Determinants. Environment and Behavior 36(6): 776-789.

Miethe, T. (1995). Fear and Withdrawal from Urban Life. The Annals of the American Academy of Political and Social Science, 539: 14-27.

Miao, J. (2004). A Note on Consumption and Savings Under Knightian Uncertainty. Annals of Economics and Finance, 5(2): 299-311.

Moore, M.H. \& Trojanowicz, R.C. (1988). Policing and the Fear of Crime. Perspectives on Policing No. 3. United States Department of Justice - National Institute of Justice.

Murata, K. (2003). Precautionary Savings and Income Uncertainty: Evidence from Japanese Micro Data. Monetary and Economic Studies, 21(3): 21-52.

Prelec, D. \& Loewenstein, G. (1998). The Red and the Black: Mental Accounting of Savings and Debt. Marketing Science, 17(1): 4-28.

Rader, N.E., Cossman, J.S. \& Porter, J.R. (2012). Fear of crime and vulnerability: Using a national sample of Americans to examine two competing paradigms. Journal of Criminal Justice 40(2): 134-141.

Rha, J., Montalto, C., \& Hanna, S. (2006). The Effect of Self-Control Mechanisms on Household Saving Behavior. Journal of Financial Counselling and Planning, 17(2): 3-16.

Rios, V. (2015). The impact of crime and violence on economic sector diversity. Working Paper. Available at $\quad \underline{\text { http://scholar.harvard.edu/files/vrios/files/riosv }}$ violencediversificationpaper.pdf $>$. Accessed January 25, 2017. 
Office for National Statistics (United Kingdom). (2012). The 2012/13 Crime Survey for England and Wales: Volume One Technical Report. London: Office for National Statistics.

Sales, S.M. (1973). Threat as a factor in authoritarianism: An Analysis of Archival Data, Journal of Personality and Social Psychology, 28(1): 44-57.

Sandmo, A. (1970). The Effect of Uncertainty on Saving Decisions. The Review of Economic Studies, 37(3): 353-360.

Sanford Police Department. (2007). Neighborhood Watch Crime Perception Survey. Available at $<$ http://www.sanfordnc.net/police/Community_Policing/survey.pdf $>$. Accessed January 24, 2017.

Schafer, J.A., Huebner, B.M., \& Bynum, T.S. (2006). Fear of crime and criminal victimization: Gender-based contrasts. Journal of Criminal Justice 34(3): 285-301.

Sibley, D. (1975). Permanent and Transitory Income Effects in a Model of Optimal Consumption with Wage Income Uncertainty. Journal of Economic Theory, 11(1): 68-82.

Skinner, J. (1988). Risky Income, Life Cycle Consumption, and Precautionary Savings. Journal of Monetary Economics, 22(2): 237-255.

Skogan, W. (1986). Fear of crime and neighborhood change. In A.S. Reiss, Jr., \& M. Tonry (Eds.), Communities and crime (p. 203-229). Chicago: University of Chicago Press.

Skogan, W.G. \& Maxfield, M.G. (1981). Coping with Crime: Individual and Neighborhood Reactions. Beverly Hills, CA: Sage Publications, Inc.

Social Weather Stations. (2016). Third Quarter 2016 Social Weather Survey: "Very Good" +64 net satisfaction rating for President Rodrigo R. Duterte. Press release. October 10. Available at $\quad<$ http://www.sws.org.ph/swsmain/artcldisppage/?artcsyscode=ART$20161006061108>$. Accessed January 26, 2017.

Taylor, R.B. \& Hale, M. (1986). Testing Alternative Models of Fear of Crime. The Journal of Criminal Law and Criminology 77(1): 151-189.

Taylor, D.G., Scheppele, K.L., \& Stinchcombe, A.L. (1979). Salience of Crime and Support for Harsher Criminal Sanctions. Social Problems 26(4): 413-424.

Taylor, R.B., Shumaker, S., \& Gottfredson, S.D. (1985). Journal of Architectural and Planning Research 2(4): 261-275.

Thaler, R., Tversky, A., Kahneman, D., \& Schwartz, A. (1997). The Effect of Myopia and Loss Aversion on Risk Taking: An Experimental Test. The Quarterly Journal of Economics 112(2): 647-661.

Van Schie, R., Donkers, B., \& B. Dellaert. (2012). Savings Adequacy Uncertainty: Driver or Obstacle to Increased Pension Contributions? Journal of Economic Psychology, 33(4): 882896.

Valera, S. \& Guàrdia, J. (2014). Perceived insecurity and fear of crime in a city with low-crime rates. Journal of Environmental Psychology 38: 195-205. 
Wachtel, P. (1977). Inflation, uncertainty, and saving behavior. In V. Zarnowitz, \& G.H. Moore

(Eds.), Explorations in Economic Research, Volume 4, Number 4 (p. 88-108.) Cambridge:

National Bureau of Economic Research.

Wanner, R.A. \& Caputo, T.C. (1987). Punitiveness, fear of crime, and perceptions of violence.

Canadian Journal of Sociology, 12(4): 331-344.

Warr, M. (1984). Fear of Victimization: Why are Women and the Elderly More Afraid? Social

Science Quarterly 65(3): 681-702.

Warr, M. (1985). Fear of Rape Among Urban Women. Social Problems 32(3): 238-250.

Warr, M. (1987). Fear of Victimization and Sensitivity to Risk. Journal of Quantitative Criminology 3(1): 29-47.

Warr, M. (2000). Fear of Crime in the United States: Avenues for Research and Policy. In Measurement and Analysis of Crime and Justice. P. 451-489. Washington: United States Department of Justice - Office of Justice Programs.

Warr, M. \& Ellison, C.G. (2000). Rethinking Social Reactions to Crime: Personal and Altruistic Fear in Family Households. American Journal of Sociology 106(3): 551-578.

Warr, M. \& Stafford, M. (1983). Fear of Victimization: A Look at the Proximate Causes. Social Forces 61(4): 1,033-1,043

Watson, J. (2003). The Relationship of Materialism to Spending Tendencies, Saving, and Debt. Journal of Economic Psychology 24(6): 723-239.

\section{Appendix 1. Complete regression tables}

Table A1.1 Logit Average Marginal Effects (Variables of Interest: Fear of Specific Crimes).

\begin{tabular}{|c|c|c|c|c|c|}
\hline \multirow[t]{2}{*}{ Variable } & $(1)$ & $(2)$ & (3) & $(4)$ & $(5)$ \\
\hline & \multicolumn{5}{|c|}{ Dep. Var. $=$ Dummy $=1$ if respondent saves; $=0$ otherwise } \\
\hline \multirow{2}{*}{ fear_pickpocket } & -0.013 & & & & \\
\hline & $(0.012)$ & & & & \\
\hline \multirow[t]{2}{*}{ fear_burglary } & & -0.007 & & & \\
\hline & & (0.012) & & & \\
\hline \multirow[t]{2}{*}{ fear_vehicle } & & & -0.009 & & \\
\hline & & & $(0.012)$ & & \\
\hline \multirow[t]{2}{*}{ fear_rape } & & & & $-0.023 *$ & \\
\hline & & & & $(0.012)$ & \\
\hline \multirow[t]{2}{*}{ fear_physviolence } & & & & & $-0.022 *$ \\
\hline & & & & & $(0.012)$ \\
\hline
\end{tabular}


Table A1.1 Continued

\begin{tabular}{|c|c|c|c|c|c|}
\hline Variable & (1) & $(2)$ & (3) & (4) & (5) \\
\hline & \multicolumn{5}{|c|}{ Dep. Var. $=$ Dummy $=1$ if respondent saves; $=0$ otherwise } \\
\hline \multirow[t]{2}{*}{ age } & $-0.019 * * *$ & $-0.019 * * *$ & $-0.019 * * *$ & $-0.019 * * *$ & $-0.019 * * *$ \\
\hline & $(0.006)$ & $(0.006)$ & $(0.006)$ & $(0.006)$ & $(0.006)$ \\
\hline \multirow[t]{2}{*}{ age squared } & $0.000 * * *$ & $0.000 * * *$ & $0.000 * *$ & $0.000 * *$ & $0.000 * * *$ \\
\hline & $(0.000)$ & $(0.000)$ & $(0.000)$ & $(0.000)$ & $(0.000)$ \\
\hline \multirow[t]{2}{*}{$\operatorname{sex}$} & -0.024 & -0.025 & -0.026 & -0.026 & -0.027 \\
\hline & $(0.030)$ & $(0.030)$ & $(0.030)$ & $(0.029)$ & $(0.030)$ \\
\hline \multirow[t]{2}{*}{ educ2 } & 0.031 & 0.030 & 0.032 & 0.028 & 0.029 \\
\hline & $(0.083)$ & $(0.083)$ & $(0.082)$ & $(0.083)$ & $(0.083)$ \\
\hline \multirow[t]{2}{*}{ educ3 } & 0.032 & 0.030 & 0.033 & 0.032 & 0.032 \\
\hline & $(0.079)$ & $(0.079)$ & $(0.078)$ & $(0.079)$ & $(0.079)$ \\
\hline \multirow[t]{2}{*}{ educ4 } & 0.110 & 0.108 & 0.111 & 0.112 & 0.112 \\
\hline & $(0.079)$ & $(0.079)$ & $(0.079)$ & $(0.079)$ & $(0.079)$ \\
\hline \multirow[t]{2}{*}{ educ5 } & 0.122 & 0.118 & 0.122 & 0.123 & 0.124 \\
\hline & $(0.080)$ & $(0.080)$ & $(0.080)$ & $(0.080)$ & $(0.080)$ \\
\hline \multirow[t]{2}{*}{ inc2 } & $0.176^{* * *}$ & $0.175 * * *$ & $0.176^{* * *}$ & $0.177 * * *$ & $0.176 * * *$ \\
\hline & $(0.026)$ & $(0.026)$ & $(0.026)$ & $(0.026)$ & $(0.026)$ \\
\hline \multirow[t]{2}{*}{ inc3 } & $0.553 * * *$ & $0.554 * * *$ & $0.554 * * *$ & $0.554 * * *$ & $0.556 * * *$ \\
\hline & $(0.108)$ & $(0.108)$ & $(0.108)$ & $(0.108)$ & $(0.109)$ \\
\hline \multirow[t]{2}{*}{ employed } & $0.101 * * *$ & $0.102 * * *$ & $0.102 * * *$ & $0.100 * * *$ & $0.100 * * *$ \\
\hline & $(0.028)$ & $(0.028)$ & $(0.028)$ & $(0.028)$ & $(0.028)$ \\
\hline \multirow[t]{2}{*}{ separate } & -0.011 & -0.011 & -0.011 & -0.011 & -0.012 \\
\hline & $(0.040)$ & $(0.040)$ & $(0.040)$ & $(0.040)$ & $(0.039)$ \\
\hline \multirow[t]{2}{*}{ single } & 0.048 & 0.048 & 0.048 & 0.049 & 0.047 \\
\hline & $(0.047)$ & $(0.047)$ & $(0.047)$ & $(0.047)$ & $(0.047)$ \\
\hline \multirow[t]{2}{*}{ victim } & 0.037 & 0.033 & 0.033 & 0.036 & 0.035 \\
\hline & $(0.027)$ & $(0.027)$ & $(0.027)$ & $(0.027)$ & $(0.027)$ \\
\hline \multirow[t]{2}{*}{ neighprob } & 0.016 & 0.015 & 0.015 & 0.019 & 0.020 \\
\hline & $(0.018)$ & $(0.019)$ & $(0.018)$ & $(0.019)$ & $(0.019)$ \\
\hline \multirow[t]{2}{*}{ media } & $0.006^{*}$ & $0.006^{*}$ & $0.006^{*}$ & $0.006^{*}$ & $0.006^{*}$ \\
\hline & $(0.003)$ & $(0.003)$ & $(0.003)$ & $(0.003)$ & $(0.003)$ \\
\hline \multirow[t]{2}{*}{ children } & $-0.033 * * *$ & $-0.033 * * *$ & $-0.032 * * *$ & $-0.032 * * *$ & $-0.032 * * *$ \\
\hline & $(0.008)$ & $(0.008)$ & $(0.008)$ & $(0.008)$ & $(0.008)$ \\
\hline \multirow[t]{2}{*}{ richer } & $0.205^{* * *}$ & $0.205 * * *$ & $0.203 * * *$ & $0.197 * * *$ & $0.198 * * *$ \\
\hline & $(0.059)$ & $(0.059)$ & $(0.059)$ & $(0.060)$ & $(0.060)$ \\
\hline \multirow[t]{2}{*}{ poorer } & $-0.293 * * *$ & $-0.294 * * *$ & $-0.297 * * *$ & $-0.292 * * *$ & $-0.295 * * *$ \\
\hline & $(0.085)$ & $(0.086)$ & $(0.086)$ & $(0.085)$ & $(0.085)$ \\
\hline Observations & 1,179 & 1,179 & 1,179 & 1,179 & 1,179 \\
\hline Pseudo R-squared & 0.1682 & 0.1677 & 0.1678 & 0.1696 & 0.1695 \\
\hline
\end{tabular}

Standard errors in parentheses; $* * * \mathrm{p}<0.01,{ }^{* *} \mathrm{p}<0.05, * \mathrm{p}<0.1$ 
CANARE, FRANCISCO AND JOPSON Fear and Crime Saving Behavior

Table A1.2 Logit Average Marginal Effects (Variables of Interest: General Fear of Crime).

\begin{tabular}{|c|c|c|}
\hline \multirow{2}{*}{ Variables } & (1) & (2) \\
\hline & \multicolumn{2}{|c|}{$\begin{array}{l}\text { Dep. Var.: Dummy }=1 \text { if } \\
\text { respondent saves; }=0 \text { otherwise }\end{array}$} \\
\hline \multirow[t]{2}{*}{ fear_neigh } & -0.013 & \\
\hline & $(0.016)$ & \\
\hline \multirow[t]{2}{*}{ fear_mm } & & $-0.036 * *$ \\
\hline & & $(0.015)$ \\
\hline \multirow[t]{2}{*}{ age } & $-0.019 * * *$ & $-0.019 * * *$ \\
\hline & $(0.006)$ & $(0.006)$ \\
\hline \multirow[t]{2}{*}{ age squared } & $0.000 * * *$ & $0.000 * * *$ \\
\hline & $(0.000)$ & $(0.000)$ \\
\hline \multirow[t]{2}{*}{ sex } & -0.022 & -0.022 \\
\hline & $(0.030)$ & $(0.030)$ \\
\hline \multirow[t]{2}{*}{ educ2 } & 0.029 & 0.038 \\
\hline & $(0.083)$ & $(0.084)$ \\
\hline \multirow[t]{2}{*}{ educ3 } & 0.031 & 0.043 \\
\hline & $(0.079)$ & $(0.080)$ \\
\hline \multirow[t]{2}{*}{ educ4 } & 0.108 & 0.122 \\
\hline & $(0.079)$ & $(0.080)$ \\
\hline \multirow[t]{2}{*}{ educ5 } & 0.118 & $0.137 *$ \\
\hline & $(0.080)$ & $(0.081)$ \\
\hline \multirow[t]{2}{*}{ inc2 } & $0.175 * * *$ & $0.172 * * *$ \\
\hline & $(0.026)$ & $(0.026)$ \\
\hline \multirow[t]{2}{*}{ inc3 } & $0.555 * * *$ & $0.553 * * *$ \\
\hline & $(0.108)$ & $(0.107)$ \\
\hline \multirow[t]{2}{*}{ employed } & $0.102 * * *$ & $0.102 * * *$ \\
\hline & $(0.028)$ & $(0.028)$ \\
\hline \multirow[t]{2}{*}{ separate } & -0.011 & -0.013 \\
\hline & $(0.040)$ & $(0.040)$ \\
\hline \multirow[t]{2}{*}{ single } & 0.048 & 0.049 \\
\hline & $(0.047)$ & $(0.047)$ \\
\hline \multirow[t]{2}{*}{ victim } & 0.033 & 0.034 \\
\hline & $(0.027)$ & $(0.026)$ \\
\hline \multirow[t]{2}{*}{ neighprob } & 0.016 & 0.019 \\
\hline & $(0.019)$ & $(0.018)$ \\
\hline \multirow[t]{2}{*}{ media } & $0.006^{*}$ & $0.006^{*}$ \\
\hline & $(0.003)$ & $(0.003)$ \\
\hline \multirow[t]{2}{*}{ children } & $-0.033 * * *$ & $-0.032 * * *$ \\
\hline & $(0.008)$ & $(0.008)$ \\
\hline richer & $0.204 * * *$ & $0.211 * * *$ \\
\hline
\end{tabular}


Review of Economic Analysis 11 (2019) 293-323

Table A1.2 Continued

\begin{tabular}{|l||c|c|}
\hline \multirow{2}{*}{\multicolumn{1}{|c||}{ Variables }} & $(1)$ & $(2)$ \\
\cline { 2 - 3 } & $\begin{array}{c}\text { Dep. Var.: Dummy }=\mathbf{1} \text { if } \\
\text { respondent saves; }=\mathbf{0} \text { otherwise }\end{array}$ \\
\hline \hline \multicolumn{1}{|c||}{ poorer } & $(0.059)$ & $(0.060)$ \\
\hline & $-0.295^{* * *}$ & $-0.301^{* * *}$ \\
\hline \multicolumn{1}{|c|}{} & $(0.086)$ & $(0.086)$ \\
\hline Observations & 1,179 & 1,179 \\
\hline Pseudo R-squared & 0.1678 & 0.1710 \\
\hline
\end{tabular}

Standard errors in parentheses; *** $\mathrm{p}<0.01, * * \mathrm{p}<0.05, * \mathrm{p}<0.1$

Table A1.3 Heckman Probit Regression Coefficients (Variables of Interest: Fear of Specific Crimes).

\begin{tabular}{|c|c|c|c|c|c|}
\hline \multirow[b]{2}{*}{ Variables } & $(1)$ & $(2)$ & (3) & (4) & $(5)$ \\
\hline & \multicolumn{5}{|c|}{$\begin{array}{l}\text { Outcome Equation (Dep. Var.: Dummy }=1 \text { if respondent saves through } \\
\text { formal means; =0 otherwise) }\end{array}$} \\
\hline \multirow[t]{2}{*}{ fear_pickpocket } & 0.043 & & & & \\
\hline & $(0.050)$ & & & & \\
\hline \multirow[t]{2}{*}{ fear_burglary } & & 0.041 & & & \\
\hline & & $(0.050)$ & & & \\
\hline \multirow[t]{2}{*}{ fear_vehicle } & & & 0.035 & & \\
\hline & & & $(0.049)$ & & \\
\hline \multirow[t]{2}{*}{ fear_rape } & & & & $0.096 * *$ & \\
\hline & & & & $(0.049)$ & \\
\hline \multirow[t]{2}{*}{ fear_physviolence } & & & & & 0.061 \\
\hline & & & & & $(0.050)$ \\
\hline \multirow[t]{2}{*}{ age } & $0.048 *$ & $0.048^{*}$ & $0.048^{*}$ & $0.049 *$ & $0.048^{*}$ \\
\hline & $(0.026)$ & $(0.026)$ & $(0.026)$ & $(0.025)$ & $(0.026)$ \\
\hline \multirow[t]{2}{*}{ age squared } & -0.000 & -0.000 & -0.000 & -0.000 & -0.000 \\
\hline & $(0.000)$ & $(0.000)$ & $(0.000)$ & $(0.000)$ & $(0.000)$ \\
\hline \multirow[t]{2}{*}{ sex } & 0.042 & 0.047 & 0.047 & 0.048 & 0.049 \\
\hline & $(0.120)$ & $(0.120)$ & $(0.120)$ & $(0.119)$ & $(0.120)$ \\
\hline \multirow[t]{2}{*}{ educ2 } & -0.093 & -0.091 & -0.105 & -0.051 & -0.076 \\
\hline & $(0.395)$ & $(0.395)$ & $(0.394)$ & $(0.390)$ & $(0.392)$ \\
\hline \multirow[t]{2}{*}{ educ3 } & 0.285 & 0.293 & 0.266 & 0.292 & 0.289 \\
\hline & $(0.372)$ & $(0.371)$ & $(0.372)$ & $(0.367)$ & $(0.369)$ \\
\hline \multirow[t]{2}{*}{ educ4 } & 0.369 & 0.374 & 0.345 & 0.355 & 0.361 \\
\hline & $(0.381)$ & $(0.379)$ & $(0.381)$ & $(0.374)$ & $(0.378)$ \\
\hline \multirow[t]{2}{*}{ educ5 } & 0.655 & $0.661 *$ & 0.627 & 0.643 & 0.646 \\
\hline & $(0.398)$ & $(0.396)$ & $(0.400)$ & $(0.391)$ & $(0.396)$ \\
\hline
\end{tabular}


CANARE, FRANCISCO AND JOPSON Fear and Crime Saving Behavior

Table A1.3 Continued

\begin{tabular}{|c|c|c|c|c|c|}
\hline Variables & (1) & $(2)$ & (3) & (4) & $(5)$ \\
\hline & \multicolumn{5}{|c|}{$\begin{array}{l}\begin{array}{l}\text { Outcome Equation (Dep. Var.: Dummy }=1 \text { if respondent saves through } \\
\text { formal means; }=0 \text { otherwise) }\end{array}\end{array}$} \\
\hline \multirow[t]{2}{*}{ inc2 } & 0.308 & 0.305 & 0.296 & 0.285 & 0.298 \\
\hline & $(0.216)$ & $(0.212)$ & $(0.215)$ & $(0.212)$ & $(0.215)$ \\
\hline \multirow[t]{2}{*}{ inc3 } & $0.901 * *$ & $0.896 * *$ & $0.890 * *$ & $0.872 * *$ & $0.881 * *$ \\
\hline & $(0.408)$ & $(0.405)$ & $(0.403)$ & $(0.396)$ & $(0.402)$ \\
\hline \multirow[t]{2}{*}{ employed } & $-0.387 * * *$ & $-0.383 * * *$ & $-0.393 * * *$ & $-0.378 * * *$ & $-0.386 * * *$ \\
\hline & $(0.129)$ & $(0.129)$ & $(0.127)$ & $(0.127)$ & $(0.128)$ \\
\hline \multirow[t]{2}{*}{ separate } & -0.000 & -0.001 & -0.001 & -0.004 & -0.001 \\
\hline & $(0.179)$ & $(0.179)$ & $(0.178)$ & $(0.177)$ & $(0.178)$ \\
\hline \multirow[t]{2}{*}{ single } & $0.447 * *$ & $0.446 * *$ & $0.442 * *$ & $0.421 * *$ & $0.437 * *$ \\
\hline & $(0.195)$ & $(0.194)$ & $(0.194)$ & $(0.193)$ & $(0.194)$ \\
\hline \multirow[t]{2}{*}{ victim } & -0.083 & -0.078 & -0.069 & -0.092 & -0.077 \\
\hline & $(0.118)$ & $(0.116)$ & $(0.116)$ & $(0.115)$ & $(0.116)$ \\
\hline \multirow[t]{2}{*}{ neighprob } & 0.004 & 0.004 & 0.008 & -0.006 & -0.003 \\
\hline & $(0.079)$ & $(0.079)$ & $(0.077)$ & $(0.077)$ & $(0.078)$ \\
\hline \multirow[t]{2}{*}{ media } & 0.012 & 0.011 & 0.011 & 0.011 & 0.011 \\
\hline & $(0.012)$ & $(0.012)$ & $(0.012)$ & $(0.012)$ & $(0.012)$ \\
\hline \multirow[t]{2}{*}{ Constant } & -1.207 & -1.200 & -1.121 & -1.249 & -1.185 \\
\hline & $(0.791)$ & $(0.790)$ & $(0.787)$ & $(0.780)$ & $(0.785)$ \\
\hline Observations & 1,179 & 1,179 & 1,179 & 1,179 & 1,179 \\
\hline Uncensored Obsns & 516 & 516 & 516 & 516 & 516 \\
\hline Wald test of indep. eqns. (p-value) & 0.0695 & 0.0608 & 0.0624 & 0.0519 & 0.0633 \\
\hline
\end{tabular}

Robust standard errors in parentheses; ${ }^{* * *} \mathrm{p}<0.01,{ }^{*} * \mathrm{p}<0.05,{ }^{*} \mathrm{p}<0.1$

\begin{tabular}{|c|c|c|c|c|c|}
\hline \multirow[b]{2}{*}{ Variables } & $(1)$ & (2) & (3) & (4) & $(5)$ \\
\hline & \multicolumn{5}{|c|}{$\begin{array}{c}\text { Selection Equation (Dep. Var.: Dummy }=1 \text { if respondent saves; }=0 \\
\text { otherwise) }\end{array}$} \\
\hline \multirow[t]{2}{*}{ fear_pickpocket } & -0.041 & & & & \\
\hline & $(0.036)$ & & & & \\
\hline \multirow[t]{2}{*}{ fear_burglary } & & -0.021 & & & \\
\hline & & $(0.036)$ & & & \\
\hline \multirow[t]{2}{*}{ fear_vehicle } & & & -0.026 & & \\
\hline & & & $(0.037)$ & & \\
\hline \multirow[t]{2}{*}{ fear_rape } & & & & $-0.068 *$ & \\
\hline & & & & $(0.037)$ & \\
\hline \multirow[t]{2}{*}{ fear_physviolence } & & & & & $-0.066^{*}$ \\
\hline & & & & & $(0.036)$ \\
\hline
\end{tabular}


Table A1.3. Continued

\begin{tabular}{|c|c|c|c|c|c|}
\hline \multirow[b]{2}{*}{ Variables } & (1) & (2) & (3) & (4) & (5) \\
\hline & \multicolumn{5}{|c|}{$\begin{array}{c}\text { Selection Equation (Dep. Var.: Dummy }=1 \text { if respondent saves; }=0 \\
\text { otherwise) }\end{array}$} \\
\hline \multirow[t]{2}{*}{ age } & $-0.060 * * *$ & $-0.060 * * *$ & $-0.059 * * *$ & $-0.059 * * *$ & $-0.060 * * *$ \\
\hline & $(0.018)$ & $(0.018)$ & $(0.018)$ & $(0.018)$ & $(0.018)$ \\
\hline \multirow[t]{2}{*}{ age squared } & $0.000 * * *$ & $0.000 * * *$ & $0.000 * * *$ & $0.000 * * *$ & $0.000 * * *$ \\
\hline & $(0.000)$ & $(0.000)$ & $(0.000)$ & $(0.000)$ & $(0.000)$ \\
\hline \multirow[t]{2}{*}{ sex } & -0.069 & -0.071 & -0.072 & -0.072 & -0.077 \\
\hline & $(0.090)$ & $(0.090)$ & $(0.090)$ & $(0.090)$ & $(0.090)$ \\
\hline \multirow[t]{2}{*}{ educ2 } & 0.125 & 0.124 & 0.130 & 0.116 & 0.121 \\
\hline & $(0.250)$ & $(0.250)$ & $(0.248)$ & $(0.249)$ & $(0.250)$ \\
\hline \multirow[t]{2}{*}{ educ3 } & 0.116 & 0.109 & 0.119 & 0.116 & 0.116 \\
\hline & $(0.239)$ & $(0.239)$ & $(0.238)$ & $(0.239)$ & $(0.239)$ \\
\hline \multirow[t]{2}{*}{ educ4 } & 0.372 & 0.366 & 0.377 & 0.380 & 0.379 \\
\hline & $(0.241)$ & $(0.241)$ & $(0.240)$ & $(0.241)$ & $(0.242)$ \\
\hline \multirow[t]{2}{*}{ educ5 } & $0.406^{*}$ & 0.394 & $0.404 *$ & $0.408 *$ & $0.410^{*}$ \\
\hline & $(0.244)$ & $(0.244)$ & $(0.243)$ & $(0.244)$ & $(0.244)$ \\
\hline \multirow[t]{2}{*}{ inc2 } & $0.541 * * *$ & $0.540 * * *$ & $0.541 * * *$ & $0.545^{* * *}$ & $0.543 * * *$ \\
\hline & $(0.085)$ & $(0.085)$ & $(0.085)$ & $(0.086)$ & $(0.085)$ \\
\hline \multirow[t]{2}{*}{ inc3 } & $1.609 * * *$ & $1.617 * * *$ & $1.616 * * *$ & $1.614 * * *$ & $1.617 * * *$ \\
\hline & $(0.294)$ & $(0.293)$ & $(0.293)$ & $(0.295)$ & $(0.295)$ \\
\hline \multirow[t]{2}{*}{ employed } & $0.313 * * *$ & $0.317 * * *$ & $0.320 * * *$ & $0.310 * * *$ & $0.312 * * *$ \\
\hline & $(0.086)$ & $(0.086)$ & $(0.086)$ & $(0.086)$ & $(0.086)$ \\
\hline \multirow[t]{2}{*}{ separate } & -0.058 & -0.058 & -0.058 & -0.059 & -0.061 \\
\hline & $(0.122)$ & $(0.122)$ & $(0.122)$ & $(0.122)$ & $(0.122)$ \\
\hline \multirow[t]{2}{*}{ single } & 0.148 & 0.146 & 0.147 & 0.151 & 0.145 \\
\hline & $(0.140)$ & $(0.140)$ & $(0.139)$ & $(0.140)$ & $(0.140)$ \\
\hline \multirow[t]{2}{*}{ victim } & 0.103 & 0.092 & 0.090 & 0.101 & 0.099 \\
\hline & $(0.084)$ & $(0.083)$ & $(0.083)$ & $(0.083)$ & $(0.083)$ \\
\hline \multirow[t]{2}{*}{ neighprob } & 0.047 & 0.042 & 0.042 & 0.055 & 0.059 \\
\hline & $(0.057)$ & $(0.057)$ & $(0.056)$ & $(0.057)$ & $(0.057)$ \\
\hline \multirow[t]{2}{*}{ media } & $0.018^{*}$ & $0.019 * *$ & $0.019 * *$ & $0.019 * *$ & $0.019 * *$ \\
\hline & $(0.009)$ & $(0.009)$ & $(0.009)$ & $(0.009)$ & $(0.009)$ \\
\hline \multirow[t]{2}{*}{ children } & $-0.095 * * *$ & $-0.095 * * *$ & $-0.094 * * *$ & $-0.093 * * *$ & $-0.094 * * *$ \\
\hline & $(0.026)$ & $(0.026)$ & $(0.026)$ & $(0.026)$ & $(0.026)$ \\
\hline \multirow[t]{2}{*}{ richer } & $0.687 * * *$ & $0.683 * * *$ & $0.679 * * *$ & $0.671 * * *$ & $0.670 * * *$ \\
\hline & $(0.171)$ & $(0.172)$ & $(0.172)$ & $(0.172)$ & $(0.173)$ \\
\hline \multirow[t]{2}{*}{ poorer } & $-0.810 * * *$ & $-0.810 * * *$ & $-0.815 * * *$ & $-0.806 * * *$ & $-0.815 * * *$ \\
\hline & $(0.226)$ & $(0.227)$ & $(0.227)$ & $(0.226)$ & $(0.227)$ \\
\hline \multirow[t]{2}{*}{ Constant } & 0.670 & 0.640 & 0.619 & 0.676 & 0.675 \\
\hline & $(0.530)$ & $(0.530)$ & $(0.526)$ & $(0.529)$ & $(0.529)$ \\
\hline
\end{tabular}

Robust standard errors in parentheses; *** $\mathrm{p}<0.01,{ }^{* *} \mathrm{p}<0.05,{ }^{*} \mathrm{p}<0.1$ 
CANARE, FRANCISCO AND JOPSON Fear and Crime Saving Behavior

Table A1.4 Heckman Probit Regression Coefficients (Variables of Interest: General Fear of Crime).

\begin{tabular}{|c|c|c|}
\hline \multirow[b]{2}{*}{ Variables } & (1) & $(2)$ \\
\hline & \multicolumn{2}{|c|}{$\begin{array}{c}\text { Outcome Equation (Dep. Var. } \\
\text { Dummy =1 if respondent saves } \\
\text { through formal means; }=0 \\
\text { otherwise) }\end{array}$} \\
\hline \multirow[t]{2}{*}{ fear neigh } & 0.081 & \\
\hline & $(0.064)$ & \\
\hline \multirow[t]{2}{*}{ fear_mm } & & $0.146^{* *}$ \\
\hline & & $(0.063)$ \\
\hline \multirow[t]{2}{*}{ age } & $0.047 *$ & $0.046^{*}$ \\
\hline & $(0.025)$ & $(0.026)$ \\
\hline \multirow[t]{2}{*}{ age squared } & -0.000 & -0.000 \\
\hline & $(0.000)$ & $(0.000)$ \\
\hline \multirow[t]{2}{*}{ sex } & 0.039 & 0.034 \\
\hline & $(0.119)$ & $(0.119)$ \\
\hline \multirow[t]{2}{*}{ educ2 } & -0.111 & -0.142 \\
\hline & $(0.393)$ & $(0.401)$ \\
\hline \multirow[t]{2}{*}{ educ3 } & 0.246 & 0.214 \\
\hline & $(0.371)$ & $(0.377)$ \\
\hline \multirow[t]{2}{*}{ educ4 } & 0.327 & 0.296 \\
\hline & $(0.378)$ & $(0.384)$ \\
\hline \multirow[t]{2}{*}{ educ5 } & 0.614 & 0.579 \\
\hline & $(0.395)$ & $(0.402)$ \\
\hline \multirow[t]{2}{*}{ inc2 } & 0.289 & 0.310 \\
\hline & $(0.208)$ & $(0.209)$ \\
\hline \multirow[t]{2}{*}{ inc3 } & $0.867 * *$ & $0.862 * *$ \\
\hline & $(0.396)$ & $(0.402)$ \\
\hline \multirow[t]{2}{*}{ employed } & $-0.399 * * *$ & $-0.406 * * *$ \\
\hline & $(0.126)$ & $(0.127)$ \\
\hline \multirow[t]{2}{*}{ separate } & 0.003 & 0.009 \\
\hline & $(0.177)$ & $(0.180)$ \\
\hline \multirow[t]{2}{*}{ single } & $0.448 * *$ & $0.438 * *$ \\
\hline & $(0.195)$ & $(0.195)$ \\
\hline \multirow[t]{2}{*}{ victim } & -0.078 & -0.073 \\
\hline & $(0.115)$ & $(0.116)$ \\
\hline \multirow[t]{2}{*}{ neighprob } & -0.003 & -0.004 \\
\hline & $(0.077)$ & $(0.077)$ \\
\hline \multirow[t]{2}{*}{ media } & 0.011 & 0.012 \\
\hline & $(0.012)$ & $(0.012)$ \\
\hline Constant & -1.141 & $-1.325^{*}$ \\
\hline
\end{tabular}


Review of Economic Analysis 11 (2019) 293-323

Table A1.4 Continued

\begin{tabular}{|l||c|c|}
\hline \multicolumn{1}{|c||}{ Variables } & $(1)$ & $(2)$ \\
\cline { 2 - 3 } & $\begin{array}{c}\text { Outcome Equation (Dep. Var.: } \\
\text { Dummy } \mathbf{1} \text { if respondent saves } \\
\text { through formal means; }=\mathbf{0} \\
\text { otherwise) }\end{array}$ \\
\hline \hline Constant (continued) & $(0.777)$ & $(0.777)$ \\
\hline Observations & 1,179 & 1,179 \\
\hline Uncensored Obsns & 516 & 516 \\
\hline Wald test of indep. eqns. (p-value) & 0.0477 & 0.0560 \\
\hline
\end{tabular}

Robust standard errors in parentheses; ${ }^{* * *} \mathrm{p}<0.01,{ }^{* *} \mathrm{p}<0.05,{ }^{*} \mathrm{p}<0.1$

\begin{tabular}{|c|c|c|}
\hline \multirow[b]{2}{*}{ Variables } & $(1)$ & $(2)$ \\
\hline & \multicolumn{2}{|c|}{$\begin{array}{c}\text { Selection Equation (Dep. Var.: } \\
\text { Dummy }=1 \text { if respondent saves; }=0 \\
\text { otherwise) }\end{array}$} \\
\hline \multirow[t]{2}{*}{ fear_neigh } & -0.034 & \\
\hline & $(0.049)$ & \\
\hline \multirow[t]{2}{*}{ fear $\mathrm{mm}$} & & $-0.114 * *$ \\
\hline & & $(0.046)$ \\
\hline \multirow[t]{2}{*}{ age } & $-0.059 * * *$ & $-0.059 * * *$ \\
\hline & $(0.018)$ & $(0.018)$ \\
\hline \multirow[t]{2}{*}{ age squared } & $0.000 * * *$ & $0.000 * * *$ \\
\hline & $(0.000)$ & $(0.000)$ \\
\hline \multirow[t]{2}{*}{$\operatorname{sex}$} & -0.065 & -0.065 \\
\hline & $(0.090)$ & $(0.090)$ \\
\hline \multirow[t]{2}{*}{ educ2 } & 0.123 & 0.146 \\
\hline & $(0.249)$ & $(0.252)$ \\
\hline \multirow[t]{2}{*}{ educ3 } & 0.115 & 0.150 \\
\hline & $(0.239)$ & $(0.242)$ \\
\hline \multirow[t]{2}{*}{ educ4 } & 0.369 & $0.409^{*}$ \\
\hline & $(0.241)$ & $(0.245)$ \\
\hline \multirow[t]{2}{*}{ educ5 } & 0.394 & $0.454^{*}$ \\
\hline & $(0.243)$ & $(0.248)$ \\
\hline \multirow[t]{2}{*}{ inc2 } & $0.538 * * *$ & $0.532 * * *$ \\
\hline & $(0.085)$ & $(0.086)$ \\
\hline \multirow[t]{2}{*}{ inc3 } & $1.626 * * *$ & $1.630 * * *$ \\
\hline & $(0.292)$ & $(0.292)$ \\
\hline \multirow[t]{2}{*}{ employed } & $0.319 * * *$ & $0.318^{* * *}$ \\
\hline & $(0.086)$ & $(0.086)$ \\
\hline \multirow[t]{2}{*}{ separate } & -0.061 & -0.067 \\
\hline & $(0.122)$ & $(0.123)$ \\
\hline
\end{tabular}


CANARE, FRANCISCO AND JOPSON Fear and Crime Saving Behavior

Table A1.4 Continued

\begin{tabular}{|c|c|c|}
\hline \multirow[b]{2}{*}{ Variables } & (1) & (2) \\
\hline & \multicolumn{2}{|c|}{$\begin{array}{c}\text { Selection Equation (Dep. Var.: } \\
\text { Dummy }=1 \text { if respondent saves; }=0 \\
\text { otherwise) }\end{array}$} \\
\hline \multirow[t]{2}{*}{ single } & 0.144 & 0.145 \\
\hline & $(0.139)$ & $(0.141)$ \\
\hline \multirow[t]{2}{*}{ victim } & 0.090 & 0.095 \\
\hline & $(0.083)$ & $(0.082)$ \\
\hline \multirow[t]{2}{*}{ neighprob } & 0.044 & 0.054 \\
\hline & $(0.058)$ & $(0.057)$ \\
\hline \multirow[t]{2}{*}{ media } & $0.018 * *$ & $0.018^{*}$ \\
\hline & $(0.009)$ & $(0.009)$ \\
\hline \multirow[t]{2}{*}{ children } & $-0.094 * * *$ & $-0.094 * * *$ \\
\hline & $(0.026)$ & $(0.026)$ \\
\hline \multirow[t]{2}{*}{ richer } & $0.683 * * *$ & $0.695 * * *$ \\
\hline & $(0.171)$ & $(0.172)$ \\
\hline \multirow[t]{2}{*}{ poorer } & $-0.810 * * *$ & $-0.828 * * *$ \\
\hline & $(0.226)$ & $(0.229)$ \\
\hline \multirow[t]{2}{*}{ Constant } & 0.638 & 0.803 \\
\hline & $(0.527)$ & $(0.530)$ \\
\hline
\end{tabular}

Robust standard errors in parentheses; ${ }^{* * *} \mathrm{p}<0.01,{ }^{* *} \mathrm{p}<0.05,{ }^{*} \mathrm{p}<0.1$ 